\title{
Correction of the Enzymic Defect in Cultured Fibroblasts from Patients with Fabry's Disease: Treatment with Purified $\alpha$-Galactosidase from Ficin
}

\author{
Glyn Dawson ${ }^{[34]}$, Reuben Matalon, and Yu-Teh Lr \\ Departments of Pediatrics and Biochemistry, Joseph P. Kennedy, Jr., Mental Retardation Research Center, \\ University of Chicago, Chicago, Illinois, USA
}

\begin{abstract}
Extract
Cultured skin fibroblasts from patients with Fabry's disease showed the characteristic $\alpha$-galactosidase deficiency and accumulated a four - to sixfold excess of trihexosylceramide (GL-3). To demonstrate the correction, cells previously labeled with $\mathrm{U}^{14} \mathrm{C}$-glucose were grown in medium containing a purified $\alpha$-galactosidase preparation obtained from ficin. The results demonstrated that $\alpha$-galactosidase was taken up rapidly from the medium and that, despite its apparent instability in the fibroblasts, it was able to become incorporated into lysosomes and catabolize the stored trihexosylceramide. These findings support the reports of therapeutic endeavors by renal transplantation and plasma infusion in Fabry's disease and suggest the extension of such studies to other related disorders in which the cultured skin fibroblasts are chemically abnormal, namely, Gaucher's disease, lactosylceramidosis, and $\mathrm{G}_{\mathrm{M} 2}$-gangliosidosis type II.
\end{abstract}

\section{Speculation}

It may be possible to replace the specific missing lysosomal hydrolase in various sphingolipidoses and other storage diseases. Although we do not propose to effect enzyme replacement therapy in vivo with a plant enzyme, such studies in tissue culture are valid, and eventually human $\alpha$-galactosidase, of comparable activity and purity, will become available.

\section{Introduction}

Fabry's disease (angiokeratoma corporis diffusum universale or trihexosylceramidosis) is an uncommon $\mathrm{X}$ linked inherited catabolic disorder characterized [22, 23 by the accumulation of large amounts of trihexosylceramide, galactosyl- $\alpha-(1 \rightarrow 4)$-galactosyl- $\beta-(1 \rightarrow 4)$ glucosyl- $\beta-(1 \rightarrow 1)-2-N$-acylsphingosine [7], in visceral tissue and the additional accumulation of digalactosylceramide, galactosyl- $\alpha-(1 \rightarrow 4)$-galactosylceramide [12], in kidney. Although the central nervous system is essen- tially unaffected, periodic crises of pain occur and this may be explained by the accumulation of GL-3 in the dorsal root ganglia [21, 23]. Death eventually results from renal failure in the 3rd decade of life or later [23]. As with many sphingolipidoses, the clinical severity is variable, possibly because of different intragenic mutations at the Fabry locus, and there have been a number of reports [23] of heterozygotes who manifest an attenuated form of the disease.

The biochemical defect in Fabry's disease was shown to be a galactosidase deficiency by Brady et al. [2] and 
more specifically, an $\alpha$-galactosidase deficiency, by Kint [10]. Fibroblasts cultured from the skin of Fabry patients exhibited both the chemical [16] and the enzymic [20] abnormality. Further, Romeo and Migeon [20] have demonstrated that fibroblasts from obligate heterozygotes could be cloned into normal and affected cell strains, the heterozygote cultures with $50 \%$ of normal enzymic activity. Mapes et al. [13] have demonstrated the presence of GL-3- $\alpha$-galactosidase activity in normal human plasma and suggested that plasma infusion might be a useful therapeutic measure for treating this visceral storage disease. The initial success of enzyme replacement by plasma infusion [14], which may have stimulated the de novo synthesis of enzyme, has prompted the use of organ transplantation (such as renal) as a means of more permanent enzyme replacement $[18,23]$. However, recent improvements in enzyme purification have indicated that replacement with pure $\alpha$-galactosidase might eventually be practical. Thus Mapes and Sweeley [15] have demonstrated that human plasma Cohn fraction IV-I can be separated into three major $\alpha$-galactosidase fractions after affinity chromatography on a column of melibiose coupled to succinylated Sepharose. Two of the fractions cleaved human kidney trihexosylceramide, but not synthetic $\alpha$-galactosides, and had different $\mathrm{pH}$ optima and different sialic acid content (accounting for the different electrophoretic mobility of the $\alpha$-galactosidases [1]). The third fraction showed activity only toward $p$-nitrophenyl- $\alpha$-D-galactoside, which indicates that caution should be used in interpreting results with synthetic substrates.

Fibroblasts have been used as a model for enzyme replacement in the severe neurologic disease, metachromatic leukodystrophy (MLD) [19, 25], and arylsulfatase A activity was then measurable for several weeks in culture. However, MLD fibroblasts do not normally accumulate sulfatide, necessitating the addition of sulfaticle to the medium before the enzyme replacement. In contrast, Fabry fibroblasts accumulate trihexosylceramide naturally so that enzyme replacement in these cells may have greater physiologic significance. Since Fabry's disease does not involve the central nervous system to an appreciable extent, thus avoiding the blood-brain barrier problem encountered with MLD or the mucopolysaccharidoses [17], successful replacement with this stable purified plant enzyme [11] should indicate a useful means of in vivo therapy when the human enzyme becomes available.

\section{Materials and Methods}

\section{Enzyme Purification}

$\alpha$-Galactosidase was purified from commercially available ficin [27] by a combination of acetone precipitation, Bio-Gel P-60 column chromatography, ammonium sulfate ( $80 \%$ saturation) precipitation, DEAESephadex A-50 chromatography, and final ammonium sulfate precipitation (0.8 saturation) as described previously [7]. The precipitate from an original $10 \mathrm{~g}$ ficin was dissolved in $1 \mathrm{ml} 0.05 \mathrm{M}$ sodium phosphate buffer, $\mathrm{pH} 7.0$, and tested for activity against both GL-3 and $p$-nitrophenyl- $\alpha$-D-galactoside $[7,11]$. Studies with other commercially available synthetic substrates showed it to be free of contaminating lysosomal hydrolases. One unit of enzyme hydrolyzes $1 \mu \mathrm{mol} p$-nitrophenyl- $\alpha$-Dgalactopyranoside or $0.01 \mu \mathrm{mol}$ trihexosylceramide/ min at $25^{\circ}$ under in vitro conditions.

\section{Chemical Analysis}

Fibroblasts for analytic studies (approximately $1 \times$ $10^{8}$ cells are needed for each analysis) were grown for 4 weeks to maximum density $\left(2.5 \times 10^{7}\right.$ cells/plate $)$ under the same conditions as described. Glycosphingolipids were isolated and characterized as described previously [4].

\section{Enzyme Replacement}

Fribroblasts were cultured from skin biopsies obtained from patients who exhibited, both clinically and biochemically, the classic symptoms of sphingolipid storage diseases; all cultures were assayed for lysosomal hydrolase levels. The Fabry cells used for enzyme replacement studies were plated initially at a density of $1 \times 10^{6}$ cells $/ 100$-mm Falcon petri dish in modified Eagle's medium [26] supplemented with ascorbic acid (100 mg/liter), $10 \%$ fetal calf serum and $10 \%$ calf serum [4]. After 7 days of growth, the cells were labeled with $\mathrm{U}^{14} \mathrm{C}$-glucose $(10 \mu \mathrm{Ci} /$ plate, specific activity $270 \mu \mathrm{Ci} / \mu \mathrm{mol}$ ) for $48 \mathrm{hr}$. At this time the medium was removed and replaced by fresh medium containing $\alpha$-galactosidase $(0.1-1.0$ units/plate). Control plates were re-fed with standard medium. After $6 \mathrm{hr}$, a further addition of 0.1-1.0 units of enzyme was made (enzyme concentration was 1 unit $/ 15 \mu \mathrm{l}$ in $0.05 \mathrm{M}$ sodium phosphate buffer, $\mathrm{pH}$ 7.0). Cells were harvested after $24 \mathrm{hr}$ of growth in the presence of enzyme and individual glycosphingolipids isolated as described previously [3, 24]. Radioactivity was determined by liquid scintillation counting after extraction of glyco- 


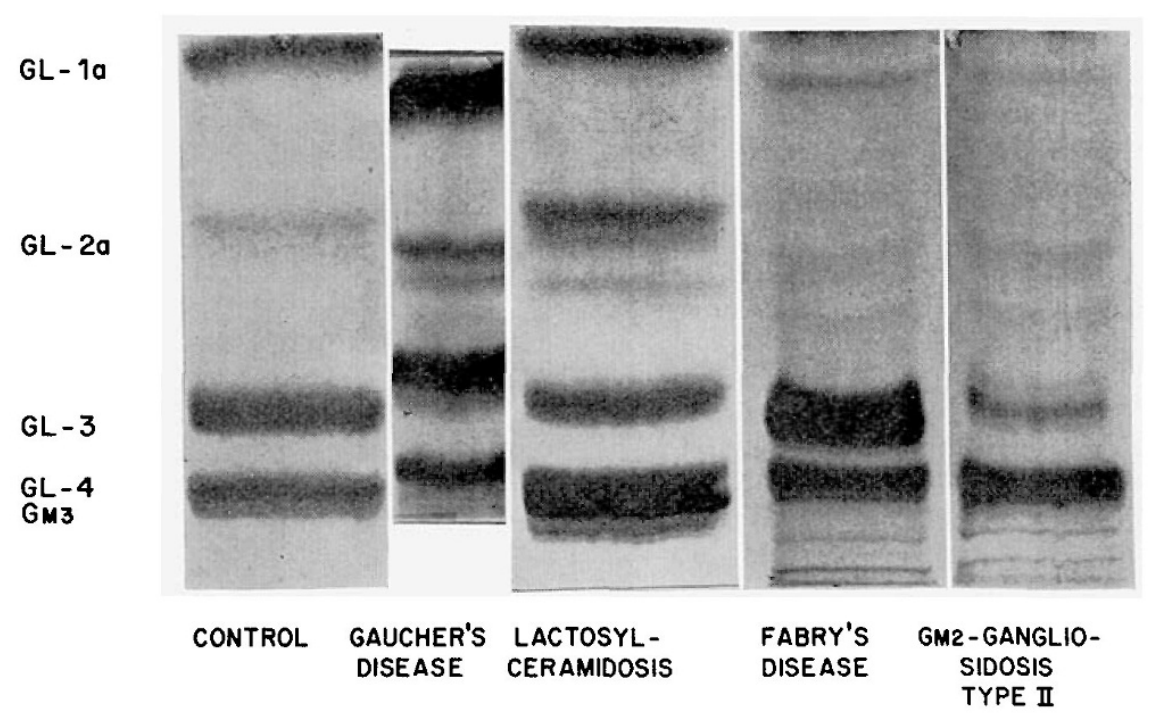

Fig. 1. Thin layer chromatographic separation of neutral glycosphingolipids $\left(G L-1 a, G L-2 a, G L-3, G L-4\right.$, and $\left.G M_{3}\right)$ from human skin fibroblasts in the solvent system chloroform, methanol, and water $(110 / 40 / 6)$.

lipids [3] from silica gel after thin layer chromatography. Enzymic analyses for $\alpha$-galactosidase activity were carried out as previously described $[5,10,20]$ on cells and media at a number of time intervals after the addition of purified $\alpha$-galactosidase to the medium (1 unit/plate of $4 \times 10^{6}$ fibroblasts in monolayer culture).

\section{Results and Discussion}

Although human skin fibroblasts cultured from patients with storage diseases exhibit the enzymic defect found in the donor patient, it is not always possible to demonstrate actual storage. Studies in this laboratory $[5,16]$ have shown that chemical abnormalities can be detected in fibroblasts from patients with Fabry's disease, Gaucher's disease, lactosylceramidosis, and Sandhoff-Jatzkewitz disease ( $\mathrm{G}_{\mathrm{M} 2}$-gangliosidosis type II) (Fig. 1), but other lipidoses such as metachromatic and globoid cell leukodystrophies or $\mathrm{G}_{\mathrm{M}_{1}}$ gangliosidosis. Of the enzymes involved in these four diseases, only $\alpha$-galactosidase and $\beta$ - $N$-acetylhexosaminidase have been purified to any great extent $[7,9,11]$. Since Fabry's disease does not include brain pathology, the prospects for effective enzyme reeplacement therapy were considered to be optimal and the fibroblast system was deemed a suitable model to determine whether exogenous enzyme could be incorporated into pre-existing lysosomes of a cell.

\section{Uptake of $\alpha$-Galactosidase by Fibroblasts}

Initial studies on the stability of ficin $\alpha$-galactosidase in tissue culture medium (Fig. 2) indicated a loss of
$70 \%$ of activity during the first $6 \mathrm{hr}$, after which the rate of loss was much more gradual. Neither fresh nor conditioned medium from normal cells was found to contain any $\alpha$-galactosidase activity. Analyses of Fabry fibroblasts after exposure to enzyme revealed that under the conditions described, $\alpha$-galactosidase activity rose from near 0 to the hydrolysis of $0.2 \mu \mathrm{mol}$ galactose $/ \mathrm{mg}$ protein $/ \mathrm{hr}$, which is the mean activity of the native $\alpha$-galactosidase in fibroblasts (Table I). In contrast to studies with arylsulfatase A [19], the ficin $\alpha$-galactosidase was fairly rapidly inactivated within the

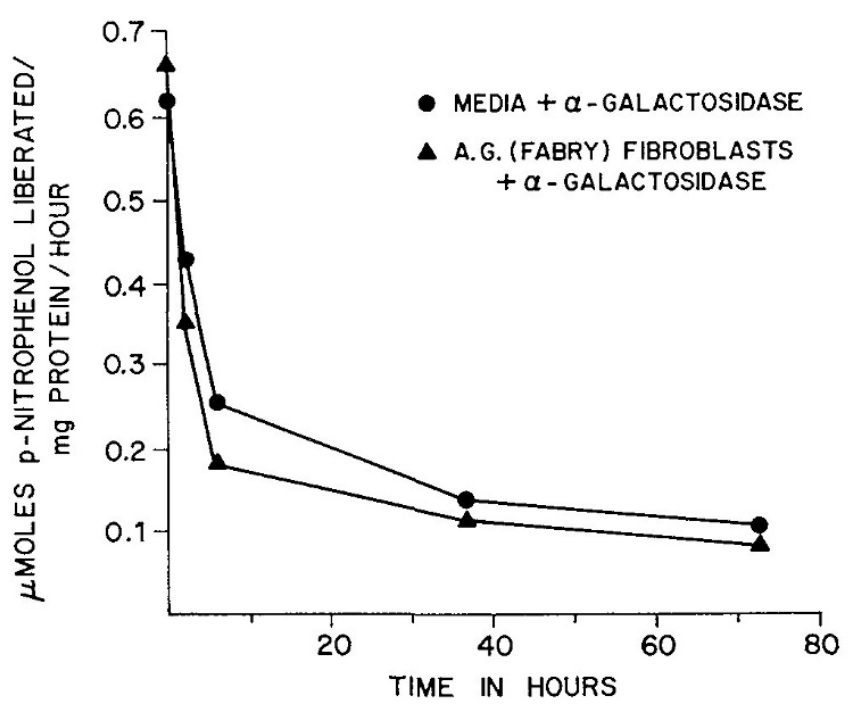

Fig. 2. Comparison of the rate of loss of $\alpha$-galactosidase activity from enzyme-treated Fabry fibroblasts $(\boldsymbol{\Lambda})$ and the surrounding tissue culture medium (-). Enzyme activity is measured with $p$ nitrophenyl- $\alpha$-D-glactoside and expressed relative to milligrams of protein as determined by the Lowry procedure. 
Table 1 . Effect of exogenous $\alpha$-galactosidase on intracellular and extracellular enzyme levels

\begin{tabular}{lcc}
\hline & \multicolumn{2}{c}{$\begin{array}{c}\text { p-Nitrophenol liberated, } \mu \mathrm{mol} / \mathrm{mg} \\
\text { protein/hr }\end{array}$} \\
\cline { 2 - 3 } \multicolumn{1}{c}{ Sample } & $\begin{array}{c}\alpha \text {-Galactosidase } \\
\text { activity under } \\
\text { standard growth } \\
\text { conditions }\end{array}$ & $\begin{array}{c}\alpha \text {-Galactosidase } \\
\text { activity } 24 \text { hr after } \\
\text { addition of } 6 \text { units } \\
\text { ficin } \alpha \text {-galactosi- } \\
\text { dase }\end{array}$ \\
\hline Normal fibroblast extract & 0.18 & \\
Fabry fibroblast extract & & \\
Patient $I(D L)$ & $<0.01$ & 0.22 \\
Patient $I I(A G)$ & 0.01 & 0.17 \\
Patient $I I I(J U)$ & $<0.01$ & 0.18 \\
Normal medium & $<0.01$ & 0.38 \\
Fabry medium & & \\
Patient $I(D L)$ & $<0.01$ & 0.32 \\
Patient $I I(A G)$ & $<0.01$ & 0.25 \\
Patient $I I I(J U)$ & $<0.01$ & 0.08 \\
\hline
\end{tabular}

cells. This could conceivably be attributed to the fact that a plant enzyme may not be stable in a mammalian cell. Similar studies have been carried out with substantially the same results on a number of different cell strains, thus an experiment on a different strain of Fabry fibroblasts (Fig. 3) indicated a slightly higher stability for the intracellular $\alpha$-galactosidase but over $50 \%$ of the enzymic activity was lost between 6 and 24 $\mathrm{hr}$ after addition of $\alpha$-galactosidase. Over this period, $88 \%$ of the $\alpha$-galactosidase was lost from the medium but despite the apparently different rate of loss, negligible activity was detected in either cells or medium after $72 \mathrm{hr}$.

\section{Detection of Trihexosylceramide Catabolism}

Because the uptake of $\alpha$-galactosidase by Fabry cells could be readily demonstrated, it was necessary to devise a sensitive assay system to detect the catabolism of GL-3 and other glycosphingolipids. We have shown previously [5] that all glycosphingolipids in human cultured skin fibroblasts are rapidly labeled when U-

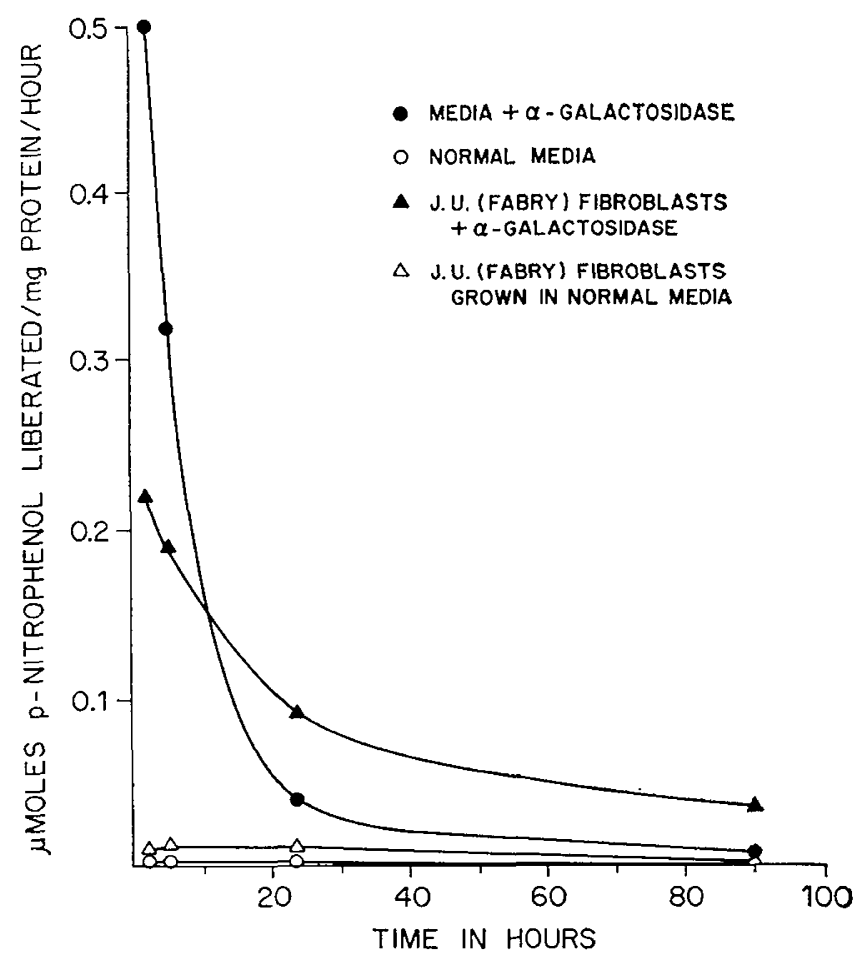

Fig. 3. Comparison of rate of loss of $\alpha$-galactosidase activity from enzyme-treated fibroblasts $(\boldsymbol{\Delta})$, the surrounding medium $(\bullet)$, and $\alpha$-galactosidase levels in untreated Fabry fibroblasts $(\triangle)$ and medium $(O)$, over this same time period.

$\left[{ }^{14} \mathrm{C}\right]$-glucose is present in the medium and that Fabry fibroblast GL-3 retains this label specifically. The difference in GL-3 concentration between treated and untreated cells was investigated after exposure to different levels of $\alpha$-galactosidase. Table II shows that adding 1 unit of enzyme to fibroblasts derived from $p a$ tients $I$ and $I I$ resulted in a negligible $(6 \%)$ amount of catabolism. However, with higher concentrations of enzyme (Table II), 6 units hydrolyzed $79 \%$ of the GL-3 in patient II (Fig. 4), and 8 units hydrolyzed $96 \%$ of

Table II. Effect of $\alpha$-galactosidase replacement in fibroblasts from patients with Fabry's disease ${ }^{1}$

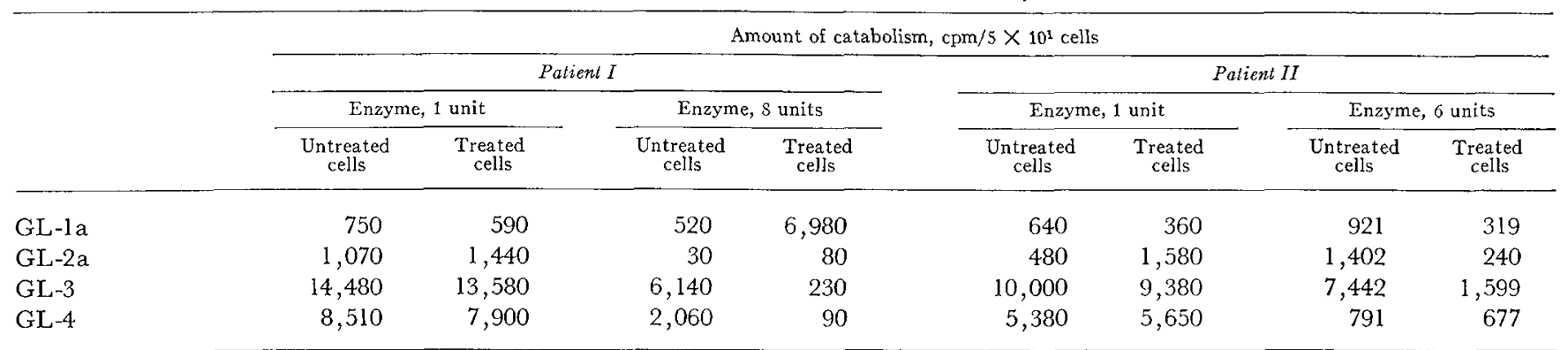

1 One unit hydrolyzes $0.01 \mu \mathrm{mol}$ galactosylgalactosylglucosylceramide (GL-3) $/ \mathrm{min}$ at $25^{\circ}$ under in vitro conditions. The concentration of GL-3 was approximately $1.3 \times 10^{-4} \mathrm{mmol} / 5.0 \times 10^{6}$ cells. 


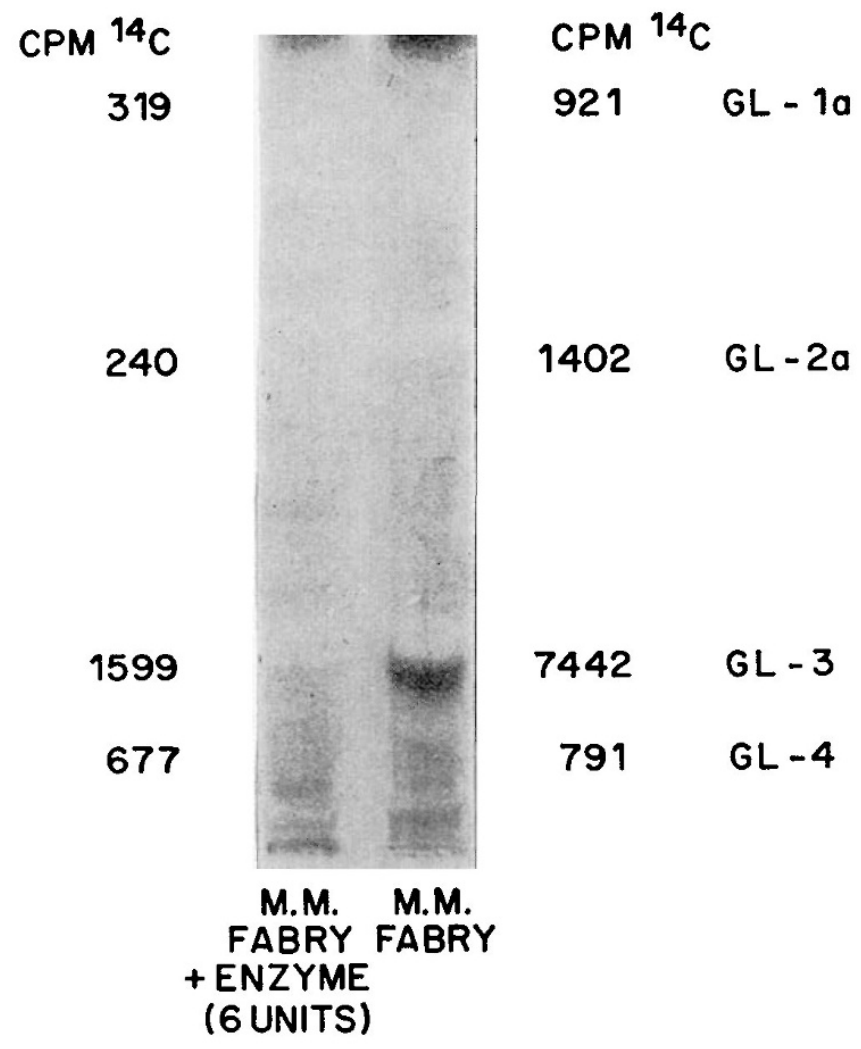

Fig. 4. Correction of inherited metabolic defect in Fabry's disease. Thin layer chromatogram of the glycosphingolipids (GL-1a, GL$2 a, G L-3$, and $G L-4)$ isolated from ${ }^{14} \mathrm{C}$-labeled Fabry fibroblasts grown under normal conditions $(M M)$ and in the presence of 6 units ficin $\alpha$-galactosidase for $24 \mathrm{hr}$ (MM Fabry + enzyme). The solvent system used was chloroform, methanol, and water (110/ 40/6). Glycosphingolipids were identified by comparison of their $R_{f}$ value on Silica Gel $G$ thin layer chromatography to that of authentic standards and their monosaccharide composition upon gas-liquid chromatographic analysis of their derived trimethylsilyl methylglycosides.

the GL-3 in patient $I$. Since the glycosphingolipids were counted directly and not fractionated into their hexose, fatty acid, and sphingosine moieties [4] it is possible that GL-la values could reflect some contamination from labeled neutral lipid. Other minor anomalies found in GL-2a and GL-4 levels may similarly seffect some artifact but the dramatic reduction in the level of GL-3, which can be seen visually (Fig. 4), is obviously the major effect.

\section{Subcellular Site of Enzyme Incorporation and Sub- strate Catabolism}

The assumption that GL-3 in Fabry's disease is stored within lysosomes has to some extent been confirmed by electron microscopy [28], although at pres- ent we have no direct proof. It, therefore, appears that $\alpha$-galactosidase is incorporated into existing lysosomes in an active form inasmuch as stored GL-3 is actually catabolized. The data presented in Table I and Figures 2 and 3 suggest that the specific activity of the enzyme is the same in both cells and medium. However, it must be pointed out that, inasmuch as the protein content of the medium is much higher than that of the cells, the efficiency of uptake of enzyme is much less than it would appear.

\section{Enzyme Replacement Therapy "in Vivo"}

Future development of enzyme replacement therapy may depend on artificial stabilization of the ficin $\alpha$-galactosidase, possibly by chemical modification or encapsulation, the purification of a human $\alpha$-galactosidase [15] which should overcome the immunologic problems associated with a plant enzyme and could have greater in vivo stability, and the demonstration that parenchymal cells other than fibroblasts are capable of taking up the enzyme. However, plasma replacement studies in Fabry's disease [14] have indicated that human $\alpha$-galactosidase is lost from the plasma at a rate approximately equal to that of our plant enzyme in tissue culture medium, and purified human $\beta$ - $N$-acetylhexosaminidase $A$ had a similarly brief half-life in the plasma of a $\mathrm{G}_{\mathrm{M} 2}$-gangliosidosis type II patient [6]. This might suggest that the brief half-life of our plant enzyme might be typical of human $\alpha$-galactosidase also but it is possible that the loss of enzymic activity from the plasma represented uptake by cells such as hepatocytes. The advantage of the ficin enzyme for these fibroblast studies is its great in vitro stability, enabling it to be shipped in soluble form without refrigeration or elaborate packing. The studies of Neufeld et al. [17] indicate that human lysosomal enzymes, partially purified from urine, retain the ability to "correct" enzymic deficiencies in fibroblasts from patients with mucopolysaccharide storage disorders. However, previous studies on mammalian $\alpha$-galactosidases $[2,13]$ have indicated a relatively low activity toward GL-3 compared with the ficin enzyme [29], whereas preparations from Aspergillus niger or Moriterella vinacea [7] showed high reactivity toward the synthetic $\alpha$-galactoside but none toward GL-3. The feasibility of administering to a patient an enzyme derived from a plant would appear to be extremely unlikely but a precedent does exist from in vivo studies on a child with type II glycogen storage disease, with the use of glycogen-degrading enzymes prepared from $A$. niger [8]. Recent advances in the purification of human $\alpha$-galactosidase [15] suggest that 
the human enzyme could be used for in vivo enzyme replacement provided that one can demonstrate its efficiency in a tissue culture system such as the one described. The use of plant enzymes would appear to be essentially preclinical in providing a rational biochemical basis for replacement therapy. It is tempting to speculate that a combination of heterozygote detection and prenatal diagnosis, together with enzyme replacement therapy, will provide an effective management of these inborn errors of metabolism in children.

\section{Summary}

Fibroblasts cultured from skin biopsies obtained from patients with Fabry's disease were almost totally deficient in $\alpha$-galactosidase activity and accumulated a four-sixfold excess of trihexosylceramide compared with normal fibroblasts grown under the same conditions. Fabry fibroblasts, in which the stored trihexosylceramide had been labeled with ${ }^{14} \mathrm{C}$-glucose, were treated with a purified $\alpha$-galactosidase from ficin, resulting in the catabolism of up to $95 \%$ of the stored lipid. This finding suggests that purified enzymes can enter pre-existing lysosomes and degrade the accumulating lipid, and provides support for the concept of enzyme replacement therapy for visceral lipid storage diseases.

\section{References and Notes}

1. Bectler, E., ANd Kufru, W.: Biochemical and electrophoretic studies of $\alpha$-galactosidase in normal man, in patients with Fabry's disease, and in equidae. Amer. J. Hum. Genet., 24: 237 (1972).

2. Brady, R. O., Gal, A. E., Bradley, R. M., Martenson, E., Warshaw, A. L., And Laster, L.: Enzymatic defect in Fabry's diseasc: Ceramidetrihexosidase deficiency. New Engl. J. Med., 276: 1163 (1967).

3. D.swson, G.: Glycosphingolipid levels in an unusual neurovisceral storage disease characterized by lactosylceramide galactosylhydrolase deficiency: Lactosylceramidosis. J. Lipid Res., 13: 207 (1972).

4. Dawson, G., Matalon, R., and Dorfman, A.: Glycosphingolipids in cultured human fibroblasts. I. Characterization and metabolism in normal fibroblasts. J. Biol. Chem., 247 5944 (1972).

5. Dawson, G., Matalon, R., and Dorfman, A.: Glycosphingolipids in cultured human fibroblasts. II. Characterization and metabolism in fibroblasts from patients with inborn exrors of glycosphingolipid and mucopolysaccharide metabolism. J. Biol. Chem., 247: 5951 (1972).

6. Desnick, R. J., SNyder, P. D., Desnick, S. J., Krivit, W., ANd Sharp, H. L.: Sandhoff's disease: Ultrastructural and biochemical studies. In: B. W. Volk and S. M. Aronson: Sphingolipids, Sphingolipidoses and Allied Disorders, p. 351. (Plenum Press, New York, 1972).
7. Hakomori, S.-I., Siddiqui, B., Lr, Y.-T., Li, S.-C., And HeLLERQuist, C. G.: Anomeric structures of globoside and ceramide trihexoside of human erythrocytes and hamster fibroblasts. J. Biol. Chem., 246: 2271 (1971).

8. Hug, G., Schubert, W. K., ANd Soukup, S.: Lysosmal diseases and fibroblast cultures: Biochemical and electron microscopic observations. In: B. W. Volk and S. M. Aronson: Sphingolipids, Sphingolipidoses and Allied Disorders, p. 37. (Plenum Press, New York, 1972).

9. Johnson, W. G., Mook, G., ANd Brady, R. O.: $\beta$-Hexosaminidase A from human placenta. Methods Enzymol., 28B: 849 (1972).

10. Kint, J. A.: Fabry's disease: Alpha-galactosidase deficiency. Science, 167: 1268 (1970).

11. LI, Y.-T., AND Lr, S.-C.: Anomeric configuration of galactose residues in ceramide trihexosides. J. Biol. Chem., 246: 3769 (1971).

12. LI, Y.-T., LI, S.-C., AND Dawson, G.: Anomeric structure of ceramide digalactoside isolated from the kidney of a patient with Fabry's disease. Biochim. Biophys. Acta, 260: 85 (1972).

13. Mapes, C. A., Anderson, R. L. ANd Sweeley, C. C.: Galactosylgactosylgulcosylceramide: Galactosyl hydrolase in normal plasma and its absence in patients with Fabry's disease. Fed. Eur. Biochem. Soc. Lett., 7: 180 (1970).

14. Mapes, C. A., Anderson, R. L., Sweeley, C. C., Desnick, R. J., AND KRIVIT, W.: Enzyme replacement in Fabry's disease, an inborn error of metabolism. Science, 169: 987 (1970).

15. Mapes, C. A., ANd Sweeley, C. C.: Substrate specificity of ceramide trihexosidase. Feb. Eur. Biochem. Soc. (In press (1973)).

16. Matalon, R., Dorfman, A., Dawson, G., ANd Sweeley, C. C.: Glycolipid and mucopolysaccharide abnormality in fibroblasts of Fabry's disease. Science, 164: 1522 (1969).

17. Neufeld, E. F., Barton, R. W., Cantz, M., Derge, J. G., Hall, C. W., Kresse, H., and Scotr, J. F.: Deficiency of specific proteins in the inborn errors of mucopolysaccharide metabolism. In: B. W. Volk, and S. M. Aronson: Sphingolipids, Sphingolipidoses and Allied Disorders, p. 187. (Plenum Press, New York, 1972).

18. Phillipart, M., Franklin, S. S., Gordon, A., Leeber, D., Hull, A. R.: Studies on the metabolic control of Fabry's disease through kidney transplantation. In: B. W. Volk and S. M. Aronson: Sphingolipids, Sphingolipidoses and Allied Disorders, p. 64l. (Plenum Press, Ner York, 1972).

19. Porter, M. T., Fluharty, A. L., and Kirara, H.: Correction of abnormal cerebroside sulfate metabolism in cultured metachromatic leukodystrophy fibroblasts. Science, 172: 1263 (1971).

20. Romeo, G., and Migeon, B. R.: Genetic inactivation of the $\alpha$-galactosidase locus in carriers of Fabry's disease. Science 170: $180(1970)$.

21. Schibanoff, J. M., Kamoshita, S., and O’Brien, J. S.: Tissue distribution of glycosphingolipids in a case of Fabry's disease. J. Lipid Res., 10: 515 (1969).

22. Sweeley, C. C., And Klionsky, B.: Fabry's disease: Classification as a sphingolipidosis and characterization of a novel glycolipid. J. Biol. Chem., 238: PC3148 (1963).

23. Sweeley, C. C., Klionsky, B., Krivit, W., and Desnick, R. J.: Fabry's disease: Glycosphingolipid. In: J. B. Wyngaarden, and D. S. Fredrickson: The Metabolic Basis of Inherited Disease, p. 663. (McGraw-Hill, New York, 1972). 
24. Vance, D. E., ANd Sweeley, C. C.: Quantitative determination of the neutral glycosyl ceramides in human blood. J. Lipid Res., 8:621 (1967).

25. Wiesmann, U. N., Rossi, E. E., and Herschkowitz, N. W.: Treatment of metachromatic leukodystrophy in fibroblasts by enzyme replacement. New Engl. J. Med., 284: 672 (1971).

26. Grand Island Biological Co., Chagrin Falls, Ohio.

27. Lot 6380, Nutritional Biochemical Corporation, Cleveland, Ohio.

28. Electron microscopy was carried out by Pei $\mathrm{Li}$ Ho, University of Chicago.

29. It is possible that figs, in common with many higher plants, have a high content of galactosyl- $\alpha-(1 \rightarrow 6)$-galactosyldiglyceride, which may be the natural substrate for $\alpha$-galactosidase and account for its high activity.

30. We wish to thank Drs. R. J. Desnick and W. Krivit, University of Minnesota, Dr. E. Engel, Vanderbilt University, and Dr. Rolf Öhman, Johns Hopkins University, for skin biopsies from patients with Fabry's disease and Dr. W. Romuk, Illinois State Pediatric Institute and Dr. J. Opitz, University of Wisconsin for skin biopsies from patients with
$\mathrm{G}_{312}$-gangliosidosis types I (Tay-Sachs disease) and II (Sandhoff-Jatzkewitz disease), respectively. The excellent technical assistance of Minerva Norella, B. Kancharla, Angelita Labudiong, Frieda Dickason, and John Oh is gratefully acknowledged.

31. The present address of Dr. Y.-T. Li is: Department of Biochemistry, Delta Regional Primate Center, University of Tulane, Covington, La.

32. Drs. G. Dawson and R. Matalon are Joseph P. Kennedy, Jr., Scholars. Dr. Y.-T. Li is the recepient of Research Career Development Award 1 KO4 HD-50280.

33. This project was supported by United States Public Health Service Grants nos. HD-04583, AM-05996, HD-06426, and NS-0926, National Science Foundation Grant no. GB-18019, and Grant no. RR-305, General Clinical Research Centers Program, Division of Research Resources, National Institutes of Health.

34. Requests for reprints should be addressed to: G. Dawson, M.D., Box 228, 950 East 59th St., Chicago, Ill. 60637 (USA).

35. Accepted for publication March 5, 1973. 